\title{
EDITORIAL
}

\section{Cum Grano Salis}

Keywords: actio popularis; erga omnes obligations; erga omnes rights; jurisdiction; International Court of Justice.

Abstract: It has to date not been examined in-depth what correlative rights and obligations the breach of an erga omnes obligation or an erga ommes right may entail. In his Separate Opinion in the Gabcikovo-Nagymaros case, Judge Weeramantry devotes one section to the legal conscquences of the involvement of erga omnes obligations in inter partes judicial procedures. This editorial analyses the relevant parts of Judge Weeramantry's Separate Opinion and explores the impact it may have on future litigation involving erga omnes issues.

Following its first appearance in the Barcelona Traction case and apart from occasional references to it by litigants or in individual opinions of judges, ${ }^{1}$ the concept of erga omnes obligations has not been prominent in the jurisprudence of the International Court of Justice for a long time. This may have contributed to the state of relative underdevelopment of the scope of the concept and the legal consequences of its involvement in judicial procedures. However, the Court and its judges now seem to have definitely abandoned their initial cautious approach to the controversial concept. In the Court's recent jurisprudence, including separate and dissenting opinions of judges, an increasing number of references can be found to the concept of erga omnes obligations and, since the East Timor case, to the concept of erga omnes rights as well. ${ }^{2}$

1. See, e.g., The Barcelona Traction, Light and Power Company, limited (Belgium v. Spain), Second Phase, Judgment of 5 lebruary 1970, 1970 ICJ Rep. 3, at 32, para. 33; Legal Consequences for States of the Continued Presence of South Africa in Namibia (South West Africa) Notwithstanding Security Council Resolution 276 (1970), Advisory Opinion of 21 June 1971, 1971 ICJ Rep. 16, at 56, para. 126; Nuclear Tests (Australia $v$. France), Judgment of 20 December 1974, 1974 ICJ Rep. 312, at 369-370 (Judges Onyema, Dillard, Jiménez de Aréchaga \& Waldock, Joint Dissenting Opinion); and The Military and Paramilitary Activities in and Against Nicaragua (Nicaragua $v$. United States of America), Merits, Judgment of 27 June 1986, 1986 ICJ Rep. 212, at 214, para. 2 (Judge Oda, Dissenting Opinion).

2. See, e.g., East Timor (Portugal $v$. Australia), Judgment of 30 June 1995, 1995 ICJ Rep. 90, at 102, para. 29, and 1995 ICJ Rep. 139, at 172-173 and 213-216 (Judge Weeramantry, Dissenting Opinion); I egality of the Threat or Use of Nuclear Weapons (Request for Advisory Opinion by the General Assembly of the United Nations), Advisory Opinion of 8 July 1996, 1996 ICJ Rep. 268, at 270-271, para. 13, and 273-274, para. 23 (President Bedjaoui, Declaration); Application

11 Leiden Journal of International Law 1-7 (1998)

(c) 1998 Kluwer Law Intemational 
As for the scope of the concept of erga omnes obligations and erga omnes rights, examples can be found in the jurisprudence of the Court itself. Mentioned in the Court's jurisprudence are the prohibition of the use of force, in particular the outlawing of acts of aggression, and the protection of human rights, in particular the outlawing of genocide, slavery, and racial discrimination. In literature, candidates such as the protection of the environment of global commons and the use of natural resources situated in areas beyond the limits of national jurisdiction are proposed. ${ }^{3}$ In his Separate Opinion in the Gabčikovo-Nagymaros case, Judge Weeramantry even seems to go a step further by relating "all cases involving environmental damage of a far-reaching and irreversible nature" to obligations that are owed erga omnes. ${ }^{4}$ Accordingly, not only the legal interests of Hungary are affected by the detrimental effects in Hungary of the Gabčíkovo-Nagymaros project, but also the legal interests of all other states in the world. This is a controversial, big step towards the recognition of erga omnes obligations related to the protection of the environment. ${ }^{5}$

As for the legal consequences of the involvement of erga omnes issues in judicial procedures, attention has primarily focused on the rights of protection in respect of the breach of erga omnes obligations and, recently, also on the establishment of jurisdiction in respect of an alleged breach of an erga omnes right.

To have locus standi in a judicial procedure, an applicant state must demonstrate a right of protection. If the applicant state does not have a legal interest of its own in a judicial procedure involving erga omnes issues, a right of protection can only be based on an actio popularis or "right resident in any member of a community to take legal action in vindication of a public interest". ${ }^{6}$ Although the Court has refused to recognize the international equivalent of an actio popularis, it has also not ruled it out altogether. It seems that the existence of actio popularis ultimately depends on the contents of the obligation concerned and not on its erga omnes character. ${ }^{7}$ The

of the Convention on the Prevention and Punishment of the Crime of Genocide (Bosnia and Herzegovina $v$. Yugoslavia), Preliminary Objections, Judgment of 11 July 1996 (not yet published); and The Gabzikovo-Nagymaros Project (Hungary/Slovakia), Judgment of 25 Scptcmbcr 1997 (not yet published), Section C (Judge Weeramantry, Separate Opinion).

3. See, e.g., R. Lefeber, Transboundary Environmental Interference and the Origin of State Liability 124-125 (1996); see also M. Ragazzi, The Concept of International Obligations Erga Omnes $154-162(1997)$.

4. See Judge Weeramantry's Separate Opinion in Gabcíkovo-Nagymaros, supra note 2, Section C.

5. See Lefeber, supra note 3, at 126-127; see also A. de Hoogh, Obligations Erga Omnes and International Crimes 41 (1996)

6. South West Africa (Ethiopia v. South Africa; Liberia v. South Africa), Sccond Phasc, Judgment of 18 July 1966, 1966 ICJ Rep. 6, at 47, para. 88.

7. See South West Africa, supra note 6, at 32, para. 44; Barcelona Traction, supra note 1, at 32 , paras. 33-34, j. 47, para. 91; see also Lefeber, supra note 3, at 116-117. 
International Law Commission, for example, has found that a corresponding right of protection accrues to "any other State" party to a multilateral treaty or bound by a relevant rule of customary international law in case of the violation of a right that las been created or is established for the protcction of human rights and fundamental freedoms. ${ }^{8}$ Since the right of peoples to self-determination is such a human right, the Court's judgment in the East Timor case comes to mind in this respect. In this case, Portugal sought to defend the right of self-determination of the people of East Timor. However, Portugal could base its locus standi in this case on the protection of an individual interest of its own, viz. the exercise of its rights as the administering power of East Timor. It, therefore, did not have to base its locus standi on the protection of a common interest, viz. the exercise of the right of selfdetermination by the people of Fast Timor. The Court did not. therefore, have to address the question of the existence of a right of protection corresponding with the erga omnes right of self-determination.

As for the establishment of jurisdiction, the question has arisen whether the litigation of erga omnes issues encroaches upon the system of consensual jurisdiction. In the Monetary Gold case, the Court held that it does not have jurisdiction if the rights or obligations of third states are involved and one of these states has not consented to the Court's jurisdiction. ${ }^{y}$ By the Court's own definition, the litigation of erga omnes issues is the concern of all states. However, if all states have a legal interest in the protection of erga omnes obligations or erga omnes rights, there may be a paradoxical and unsatisfactory catch in the recognition of such obligations and such rights: the current system of non-compulsory jurisdiction would, in practice, prevent the Court from exercising jurisdiction in cases involving erga omnes issues. Of course, one can turn the edges of this conclusion. On the one hand, it has already been explained that the involvement of erga omnes issues does not automatically entail a corresponding right of protection. In the absence of such a right, a claim will not be admissible. The existence of such a right depends, as said, on the contents of the erga omnes obligation or erga omnes right concerned. On the other hand, it appears from the Monetary Gold case that it is not sufficient for legal interests of a third state to be merely affected by a decision of the Court. The Court will only decline jurisdiction if said interests are the "very subject-matter of the decision". ${ }^{10}$ Hence, it remains to be seen whether and under what circumstances there is any room left for the Court to exercise jurisdiction over erga omnes issues.

8. See Art. 5(2.e.iii) of the 1996 ILC Draft Articles on State Responsibility, UN Doc. A/CN.4/T 533 and Add 1 (1996).

9. See also Monetary Gold Removed From Rome in 1943 (Italy $v$. France, United Kingdom, and United States of America), Judgment of 15 June 1954, 1954 ICI Rep. 19, at 32.

10. Id. 
In the East Timor case, the Court found that it did not have jurisdiction over the alleged breach by Australia of its obligation to respect the erga omnes right to self-determination of the people of East Timor. The alleged breach consisted of the conclusion of a treaty between Australia and Indonesia on the exploitation of the natural resources off the coast of East Timor. According to the Court, it could not rule in this case without an evaluation of the lawfulness of the conduct of Indonesia. In other words, the legal interests of Indonesia would form the very subject-matter of the decision and, therefore, the consent of Indonesia to the Court's jurisdiction was indispensable. Yet, the question arises what the very subject-matter of a decision is it erga omnes issues are involved. If the determination of rights and obligations of any state are the very subject-matter of a decision, as can be inferred from Australia's principal objection in the East Timor case, the Court could only exercise jurisdiction over erga omnes issues if all states consent to the Court's jurisdiction. However, the Court did not follow Australia's reasoning and does not seem to have locked the door on the litigation of ergu umnes issues. It has only said that the evaluation of the lawfulness of the conduct of another state belongs to the very subject-matter of a decision. Whether it was really necessary to evaluate the lawfulness of the conduct of Indonesia in the East Timor case can be disputed." What matters is the opinion of the Court that the establishment of liability for an internationally wrongful act of a third state - and not the determination of rights and obligations of a third state - is decisive for the application of the Monetary Gold decision.

Apart from the issues of rights of protection and jurisdiction, it has to date not been examined in-depth what correlative rights and obligations the breach of an erga omnes obligation or an erga omnes right may entail. However, in his Separate Opinion in the Gabčkovo-Nagymaros case, Judge Weeramantry devotes one section to the legal consequences of the involvement of erga omnes issues in inter partes judicial procedures. According to Judge Weeramantry, these consequences are different in said procedures, because

[w]c have entered an era of internationa! law in which international law subserves not only the interests of individual States, but looks beyond them and their parochial concerns to the greater interests of humanity and planetary welfare. In addressing such problems, which transcend the individual rights and obligations

11. See, on the incompatibility of this decision with the Court's decision in Certain Phosphate Lands in Nauru (Nauru v. Australia), Preliminary Objections, Judgment of 26 June 1992, 1992 ICJ Rep. 240, I.G.M. Scobbie \& C.J. Drew, Self-Determination Undetermined: The Case of East Timor, 9 LJIL 185, at 207-208 (1996); and Dissenting Opinion of Judge Weeramantry in East Timor, supra note 2, at 156 et seq. But see, for the opinion of the Court in East Timor, supra note 2, at 104-105, para. 34 . 
of the litigating States, international law will need to look beyond procedural rules fashioned for purely inter partes litigation. ${ }^{12}$

Indeed, the "greater interests of humanity and planetary welfare" are at the root of the introduction in international law of concepts that are meant to protect common interests and basic moral values, such as erga omnes obligations and erga omnes rights, ius cogens, and international crimes ${ }^{13}$ For this reason, the term 'erga omnes obligation' is not the generic term of a set of bilaterally structured obligations, but of one integrally structured obligation linking states upon which the obligation is incumbent to the international community as a whole and, thus, to all other states. Therefore, the involvement of erga omnes issues transgresses the traditional bilateral approach to the settlement of disputes.

In the Gabcikovo-Nagymaros case, the Court considered the legal intricacies of a dispute between Hungary and Slovakia with respect to the operation of a barrage system in the Danube. Arrangements for this project had been laid down in a treaty between the former Czechoslovakia and Hungary, viz. the 1977 Treaty Concerning the Construction and Operation of the Gabčíkovo-Nagymaros System of Locks. ${ }^{14}$ The project involved, inter alia, the construction of a canal, a barrage, and hydro-electric power stations as well as the creation of a reservoir. As a result of the project, part of Hungarian territory would be inundated and the course of the river diverted. The proclaimed aim of the mutually beneficial project was to forestall flooding, to facilitate navigation, and to increase energy supply. However, in addition to these beneficial effects and anticipated adverse environmental effects, the project was later found to have significant unforeseen adverse environmental effects as well. Since these adverse environmental effects could allegedly not be overcome by a technical correction of the project, Hungary cventually took the position that the project and, hence, the Treaty, should be abandoned. It decided to stop work on the project on 13 May 1989, then pushed for renegotiation of the Treaty in vain, and subsequently unilaterally terminated it as of 25 May 1992.

However, in spite of awareness of the adverse environmental impact of the project and even after the radical changes in its political orientation, Hungary nevertheless proceeded with planning and carrying out the project. In early 1989 , Hungary even agreed to modifications in the timetable of the project in order to speed it up. Therefore, Judge Weeramantry found that all ingredients of a legally binding estoppel were present in this case. In inter

12. See Judge Weeramantry's Scparate Opinion in Gabcíkovo-Nagymaros, supra note 2, Section C.

13. See, on the differences between these concepts, R. Iefeher, The Exercise of Jurisdiction in the Antarctic Region and the Changing Political Structure of Intemational Law: The International Community and Common Interests, 21 NYIL 81, at 92 (1990).

14. See 32 ILM 1247 (1993). 
partes litigation, the finding of a legally binding estoppel normally renders a claim inadmissible. Accordingly, Hungary would have been prevented from suspending the works in May 1989 and terminating the bilateral treaty in May 1992. Although all conditions of a legally binding estoppel were thus met in the present case, Judge Weeramantry questions whether it is appropriate to apply all the rules of inter partes litigation in this particular case:

[t]he Court, in the discharge of its traditional duty of deciding between the parties, makes the decision which is in accordance with justice and fairness between the parties. The procedure it follows is largely adversarial. Yet this scarcely does justice to rights and obligations of an erga omnes character - least of all in cases involving environmental damage of a far-reaching and irreversible nature. [...] There has been conduct on the part of Hungary which, in ordinary inter partes litigation, would prevent it from taking up wholly contradictory positions. But can momentous environmental issues be decided on the basis of such inter partes conduct? In cases where the erga omnes issues are of sufficient importance, I would think not. ${ }^{15}$

Accordingly, the involvement of erga omnes issues of "sufficient importance' would have serious, but logical procedural consequences for inter partes litigation. However, the Court did not follow Judge Weeramantry's line of reasoning. It did not pay any attention to the issue of estoppel in its judgment, thus avoiding the need to rule on such a complicated and controversial issue as erga omnes issues are.

Following Judge Weeramantry's line of reasoning, the question arises what other legal instruments would no longer be of avail to the parties in inter partes litigation to escape liability ex dclicto or state responsibility. Judge Weeramantry only refers to estoppel. Accordingly, a litigant cannot rely on the other litigant's prior conduct, acquiescence, or waivers of liability. In addition to estoppel, it would seem that not all circumstances precluding wrongfulness could be invoked to justify an act not in conformity with an erga omnes obligation or erga omnes right. ${ }^{16}$ In particular, defences based on consent or the resort to countermeasures have their origin in bilateral relationships between states. The resort to a countermeasure is only justifiable vis-à-vis the perpetrator of an internationally wrongful act, but not $v i s-\grave{a}-v i s$ the international community as a whole. A waiver or consent cannot even be legally given. The state seeking a waiver of consent to justify an act not in conformity with an erga omnes obligation or erga omnes right can only be excused if it would obtain a waiver or the consent of the international community as a whole. Only if one would adopt the position that an erga omnes obligation consists of a set of bilaterally structured obligations,

15. See Judge Weeramantry's Separate Opinion in Gabðíkovo-Nagymaros, supra note 2, Section C.

16. See also Lefeber, supra note 3, at 100-101. 
would it be possible for individual states to waive the legal consequences of a breach of an erga omnes obligation or erga omnes right, or to consent to such a breach. However, such an approach cannot be reconciled with the integral structure of erga omnes obligations and erga omnes rights.

In contrast, defences based on other circumstances precluding wrongfulness do not seem to follow suit and can thus be invoked in inter partes litigation involving ergu omnes issues. As for the right of self-defence, this is self-evident. The use of force by a state that is the object of an armed attack by another state is justifiable, even though the use of force is not in conformity with an erga omnes obligation. Otherwise, there would be no right of self-defense. In my opinion, one should come to the same conclusion if it was materially impossible for a state to act otherwise than it did (force majeure and fortuitous event); if the author of the conduct seeks to save his life or that of persons entrusted to his care (distress); or even if a state seeks to safeguard an essential interest against a grave and imminent peril (state of necessity). However, a state of necessity would not preclude the wrongfulness of an act of the state if the erga omnes obligation with which the act of the state is not in conformity arises out of a peremptory norm of international law. ${ }^{17}$

Judge Weeramantry's Separate Opinion in the Gabcikovo-Nagymaros case has provided us with yet a new insight into the mystery that erga omnes obligations and erga omnes rights still are. Clearly, the increasing number of references to and analyses of erga omnes obligations and erga omnes rights in the Court's jurisprudence has superseded Judge De Castro's observation that the recognition of erga omnes obligations by the Court in the Barcelona Traction case should be taken "cum grano salis".

René Lefeber

17. See Art. 33(2.a) of the 1996 ILC Draft Articles on State Responsibility, supra note 8 .

18. See Nuclear Tests (Australia v. France), Judgment of 20 December 1974, 1974 ICJ Rep. 372, at 387, para. 2 (Judge De Castro, Dissenting Opinion) 